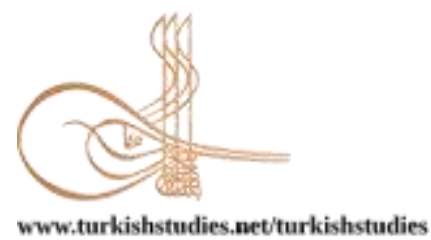

Turkish Studies

\title{
Salgını Aldığımız Önlemler mi Yavaşlattı: Salgına Önlem Alma Miktarı ile Önlemlerin Algılanan Faydalılığı ve Zorluğu, Sorumluluk Algısı ve Baş Etme Yolları Arasındaki İlişki
}

\author{
Did the Precautions We Took Slow the Pandemic: The Amount of Precautionary Behaviors \\ Taken Against the Pandemic and Its Relationship with Perceived Benefit and Difficulty of \\ Precautions, Perception of Responsibility and Ways of Coping
}

\author{
Aslı Erşan* - Perihan Cengiz ${ }^{* *}$ - Alpay Çiller ${ }^{* * *}$ - Mehmet Şakiroğlu****
}

\begin{abstract}
The main purpose of this study is to examine the relationship between the precautionary behaviours taken against pandemic and its perceived difficulty and benefit, perception of responsibility and ways of coping. In line with this purpose, the data which is collected from 299 people (207 female, 92 male) were analyzed. Participants completed six forms that are demographic information form, perceived responsibility measurement, reasons for taking precautions and not taking precautions, Taking Precautions Against Pandemic Scale and Ways of Coping Scale. The data was collected over the internet via the scales specified. Results indicated that there was a significant difference between the genders in favor of women in terms of the amount of precaution taken. According to the results of the analysis, it was found that the perceived benefit, perceived difficulty, and problem focused / optimistic coping approach predicted the precautionary behavior. The more beneficial a precaution is perceived, that precaution is implemented most. However, the more difficult a precaution is perceived, that precaution is implemented less. People who use problem focused / optimistic coping strategies take precautions most. In addition to this, it was found that the perceived benefit of the precautions variable mediated both the relationship between the problem focused / optimistic coping approach and precautionary behaviors and the relationship between the perceived difficulty of the precaution and the precautionary behavior.
\end{abstract}

\footnotetext{
* Psikolog, Aydın Adnan Menderes Üniversitesi, Fen Edebiyat Fakültesi, Klinik Psikoloji Bölümü Psychologist, Aydin Adnan Menderes University, Faculty of Arts and Sciences, Department of Clinical Psychology ORCID 0000-0003-1294-073X

asliersan@outlook.com

** Psikolog, Aydın Adnan Menderes Üniversitesi, Fen Edebiyat Fakültesi, Klinik Psikoloji Bölümü Psychologist, Aydin Adnan Menderes University, Faculty of Arts and Sciences, Department of Clinical Psychology ORCID 0000-0001-5360-4359 psk.perihancengiz@gmail.com

**** Arş. Gör., Tokat Gazi Osman Paşa Üniversitesi, Fen Edebiyat Fakültesi, Psikoloji Bölümü Res. Asst., Tokat Gazi Osman Pasa University, Faculty of Arts and Sciences, Department of Psychology ORCID 0000-0003-2988-8288 cilleralpay@gmail.com

***** Dr. Öğr. Üyesi, Aydın Adnan Menderes Üniversitesi, Fen Edebiyat Fakültesi, Psikoloji Bölümü Asst. Prof. Dr., Aydin Adnan Menderes University, Faculty of Letters, Department of Psychology ORCID 0000-0001-8990-621X mehmet.sakiroglu@adu.edu.tr

Cite as/ Atıf: Erşan, A., Cengiz, P., Çiller, A., \& Şakiroğlu, M.. (2021). Salgını aldığımız önlemler mi yavaşlattı: Salgına önlem alma miktarı ile önlemlerin algılanan faydalılı̆̆1 ve zorluğu, sorumluluk algısı ve baş etme yolları arasındaki ilişki. Turkish Studies, 16(1), 203-217. https://dx.doi.org/10.7827/TurkishStudies.46567

Received/Geliș: 24 September/Eylül 2020

Checked by plagiarism software

Accepted/Kabul: 20 Şubat/February 2021 
Structured Abstract: COVID-19 type viral infection disease situation has been characterised as a pandemic by the World Health Organization on March 11, 2020 due to its alarming levels of spread throughout the world since the first day of the disease (Metintaş, 2020; İşsever, İşsever \& Öztan, 2020; Bedford, Enria, Giesecke, Heymann, Ihekweazu, Kobinger \& Ungchusak, 2020). Since May 26, 2020, Covid-19, which is still spreading in our country and many other countries, has caused changes in the lives of many people in the world due to governments' obligations to comply with precautions taken against the virus and the high risk of virus transmission. Therefore, it affected large masses. Within the scope of combating this new type of Corona Virus, recommended or required precautions by governments include wearing masks, avoiding crowded environments, lockdown and keeping a physical distance between other people (Aktürk, 2020). In this study, the main purpose is to examine the relationship between the precautionary behaviours taken against pandemic and its perceived difficulty and benefit, perception of responsibility and ways of coping. Our hypotheses are (1) the precautionary behaviors that are perceived as beneficial will be taken more (2) the precautionary behaviors that are perceived as difficult to apply will be taken less. (3) individuals who perceive taking precautions as their own responsibility will take more precautions than others who consider it as the responsibility of others (e.g. municipalities, governorships, the ministry of health or the state) (4) People who use problem focused coping approach engage in precautionary behaviors more (5) People who use fatalistic coping approach engage in precautionary behaviors less (6) People who use helplessness approach engage in precautionary behaviors less (7) People who use seeking social support approach engage in precautionary behaviors more (8) People who use problem focused coping approach perceive precautions more beneficial. The study was conducted with 299 people, of which 207 (69.2\%) were female and 92 (30.8\%) were male. Age of these participants ranged between 19 and 76 years (mean: $43.5 \pm 11.4$ years). The participants mostly participated in the cities of Aydın (38 people) and Izmir (38 people) and two of them together constitute $25.40 \%$ of the sample. Data were collected by a questionnaire developed for the purposes of present study and that questionnaire explored a large number of topics relating to precautionay behavior taken against pandemic. Participants completed six forms which are demographic information form, perceived responsibility measurement, reasons for taking precautions and not taking precautions, Taking Precautions Against Pandemic Scale and Ways of Coping Scale. The data was collected over the internet. Results indicated that there was a statistically significant difference between the genders in favor of women in terms of the amount of precaution taken. Washing hands with plenty of water and soap when came from outside, wearing mask while outdoors and physical (social) distancing were the most implemented precausions by participants. These precautions were excessively emphasized precautions against virus by the authorities. Wearing mask at home and wearing gloves at home were least implemented precausions by participants. When participants' reasons for taking and not taking precautions were analyzed, it was found that people mostly take precautions to protect their family and themselves and people mostly do not take precautions due to living in a virus-safe area and having to go to work. According to the results of the analysis, it was found that the perceived benefit, perceived difficulty, and problem focused / optimistic coping approach predict the precautionary behaviors and the perceived responsibility variable does not predict the precautionary behaviors. The more beneficial a precaution is perceived, that precaution is implemented most. However, the more difficult a precaution is perceived, that precaution is implemented less. The subdimensions obtained as a result of the factor analysis of Ways of Coping Scales are as follows; problem focused / optimistic coping approach, fatalistic approach, self-accusatory approach and seeking social support. The social support seeking and self-accusatory approach subdimensions were mostly created by using theoratical rationale. According to the results of the analysis, people who use problem focused / optimistic coping strategies take precautions most and fatalistic coping approach, self-accusatory approach and seeking social support do not predict precautionay behaviors. The perceived benefit of the precaution mediated both the relationship between the problem focused / optimistic coping approach and precautionary behavior and the relationship between the perceived difficulty of the precaution and the precautionary behavior. It means that even if a precaution is perceived as difficult to take, people will take this precaution when they are convinced about benefit of the precaution.

Keywords: Psychology, precautionary behavior, ways of coping, perceived benefit, perceived difficulty, perceived responsibility. 
Öz: Bu çalışmanın temel amacı salgına karşı önlem alma davranışı ile önlemin algılanan faydalılığı ve zorluğu, sorumluluk algısı ve baş etme yolları arasındaki ilişkinin incelenmesidir. Bireylerin onlara önerilen ya da zorunlu kılınan bu önlemlere uymalarını etkileyen psikolojik faktörler arasında sorumluluk algısının da yer aldığı düşünülmektedir. Bu nedenle bu araştırma kapsamında bireylerin sorumluluk algılarının Covid-19 salgınına karşı önlem alma davranışını da etkileyeceği düşünülmüştür. Bu amaç kapsamında 299 kişiden (207 kadın,92 erkek) toplanan veriler analiz edilmiştir. Araştırmanın verileri; demografik bilgi formu, algılanan sorumluluk ölçümü, önlem alma ve almama nedenleri formu, Salgına Önlem Ölçeği ve Baş Etme Yolları Ölçeği (Ways of Coping) olmak üzere toplam altı form ile toplanmıştır. Veri toplama işlemi, belirtilen ölçekler aracılığıyla internet üzerinden toplanmıştır. Önlem alma miktarı açısından cinsiyetler arasında kadınların lehinde anlamlı bir farklılık bulunmuştur. Analiz sonuçlarına göre algılanan faydalılı̆̆ın, algılanan zorluğun ve problem odaklı-iyimser baş etme yaklaşımının önlem alma davranışını yordadığı bulunmuştur. Alınacak önlem ne kadar faydalı algılanırsa, o önlem o kadar çok uygulanmaktadır. Bununla birlikte alınacak önlem ne kadar zor algılanırsa, o önlem o kadar az uygulanmaktadır. Problem odaklı / iyimser baş etme stratejisini kullanan kişiler salgına karşı daha çok önlem almaktadır. Buna ek olarak, önlemin algılanan faydalılığı değişkeninin problem odaklıiyimser baş etme ile önlem alma davranışı arasındaki ilişkiye ve önlemin algılanan zorluğu ile önlem alma davranışı arasındaki ilişkiye aracılık ettiği bulunmuştur.

Anahtar kelimeler: Psikoloji, önlem alma davranışı, baş etme yolları, algılanan fayda, algılanan zorluk, algilanan sorumluluk.

\section{Giriş}

Dünya üzerinde ilk olarak 31 Aralık 2019 tarihinde Çin'in Wuhan kentinde kayıtlara geçen Türkiye'de ise ilk olarak 11 Mart 2020 tarihinde görülen Covid-19 türü viral enfeksiyon hastalığı ortaya çıktığı ilk günden itibaren dünya üzerinde hızla yayılımını sürdürmesi nedeniyle 11 Mart 2020 tarihinde Dünya Sağlık Örgütü tarafından pandemi ilan edilmiştir (Metintaş, 2020; İşsever, İşsever ve Öztan, 2020; Bedford, Enria, Giesecke, Heymann, Ihekweazu, Kobinger ve Ungchusak, 2020). 26 Mayıs 2020 tarihi itibariyle ülkemizde ve daha pek çok başka ülkede hala yayılmaya devam eden Covid-19 gerek virüse karşı hükümetlerce alınan önlemlere uyma zorunluğu getirilmesi nedeniyle gerek bulaşma riskinin yüksek olması nedeniyle dünya üzerinde pek çok insanın hayatında değişikliklere yol açmış ve bu nedenle geniş kitleleri etkisi altına almıştır. Bu yeni tip korona virüs ile mücadele kapsamında hükümetlerce önerilen ya da zorunlu kılınan önlemler arasında maske takmak, kalabalık ortamlardan kaçınmak, sokağa çıkmamak ve diğer insanlar ile aramızda fiziksel mesafe bulundurmak gibi önlemler bulunmaktadır (Aktürk, 2020).

\section{Sorumluluk Algisı}

Bireylerin onlara önerilen ya da zorunlu kılınan bu önlemlere uymalarını etkileyen psikolojik faktörler arasında sorumluluk algısının da yer aldığı düşünülmektedir. Sorumluluk kavramı Türk Dil Kurumu tarafindan "kişinin kendi davranışlarını veya kendi yetki alanına giren herhangi bir olayın sonuçlarını üstlenmesi, sorum, mesuliyet" olarak tanımlanmaktadır (www.tdk.gov.tr, 2020). Bu çerçevede sorumluluk algisı kavramı ise kişinin kendi davranışlarının olay üzerinde yarattığı sonuçların farkındalığını ifade etmektedir. Sorumluluk algısının eğitim ve iş yaşamı gibi pek çok farklı alanlardaki davranışları etkilediği bilinmektedir (Sezer, Çoban, 2016; Bayraktaroğlu, Yılmaz ve Murat, 2014). Bu nedenle bu araştırma kapsamında bireylerin sorumluluk algılarının Covid-19 salgınına karşı önlem alma davranışını da etkileyeceği; önlem almayı kendi sorumluluğu olarak gören bireylerin, önlem almayı başkalarının (örneğin; belediyelerin, valiliklerin, sağlık bakanlığının yahut devletin) sorumluluğu olarak görenlere göre daha fazla önlem alacağı düşünülmektedir. 


\section{Baş Etme Yolları}

Folkman ve Lazarus (1988) baş etmeyi, kişinin kaynaklarını aşan veya zorlayan belirli iç ve dış talepleri yönetmek için yapılan çok çeşitli bilişsel ve davranışsal çabalar olarak tanımlamışlardır. Birey bir stresör ile karşı karşıya kaldığında, stresin büyüklüğünü ve kendi başa çıkma yeterliliğini bir arada değerlendirip nasıl başa çıkabileceğine karar verir. $\mathrm{Bu}$ değerlendirmeye göre kişi stresörün yarattığı etkiyi azaltmak amacıyla bir baş etme stratejisini tercih etmektedir. Bu başa çıkma stratejileri iki ana kategoriye ayrılabilir; problem odaklı başa çıkma ve duygu odaklı başa çıkma. Problem odaklı baş etmede stresin kaynağı olan kişi-çevre ilișkisinin yönetimi veya değiștirilmesi esas iken duygu odaklı baș etmede stresli duyguların düzenlenmesi esastır (Folkman ve Lazarus, 1980). Problem odaklı başa çıkma stratejisinin çoğunlukla duygu odaklı başa çıkmaya göre stresörün etkisini azaltmada daha etkili olduğu düşünülür, çünkü problemlere ve problemlerin nedenlerine çözüm üretmeye yönelik davranışlara odaklanır (Folkman ve Moskowitz, 2000). Yapılan çalışmalar duygu durumunu düzenleme çabasını içeren duygu odaklı baş etmeyi, yeni duruma uyumu zorlaştıran bir faktör olarak bulurken, stresörleri fark etme ve doğrudan onların üstesinden gelme çabasını içeren problem yönelimli baş etmeyi ise daha iyi uyum sağlama ile ilişkili bulmuştur (Karanc1, Alkan, Akşit, Balta ve Sucuoğlu, 1999). Bu bağlamda hangi baş etme stratejisinin önlem alma davranış1 ile daha ilişkili olduğunun incelenmesi çalışmanın amaçları arasında yer almaktadır. Bireyin psikolojik kaynakları tehdidin boyutuna göre yetersiz olarak görüldüğünde artan tehdit düzeyleri, problem odaklı başa çıkma stratejisinin seçilmesini azaltmaktır (Unger, Kipke, Simon, Johnson, Montgomery ve Iverson, 1998). Bu nedenle kişinin adaptif bir baş etme yöntemi seçmesi için kaynaklarını yeterli görmesi gerekir. Salgına önlem almak konusunu düşünecek olursak buradaki temel kaynak hangi önlemlerin alınabileceği konusundaki bilgi ve gerekli materyali elde etmek olabilir.

Problem odaklı başa çıkma stratejileri kullanan bir birey, problemi doğrudan davranış yoluyla çözmeyi veya onu değiştirmeyi amaçlar. Problem odaklı başa çıkma plan yapma, harekete geçme ve yardım arama davranışı gibi konuları içerisinde barındırır. Salgına önlem alma konusunda, duygusal odaklı başa çıkma stratejisi kullanan bireylerden daha fazla problem odaklı başa çıkma stratejisini kullanan kişilerin salgına önlem alma davranışlarına katılması beklenmektedir. Bununla birlikte duygu odaklı başa çıkma inkar etme ve kaderci/teslimiyetçi düşünme gibi stresörün etkisini azaltmaya yönelik uyumsuz olan davranışları içerir (Carver, Weintraub ve Scheier, 1989). Salgın kontrol edilmesi güç bir olaydır ve bazı bireyler stresli olayı kontrol edilmesi güç olarak algılarsa inkar ederek başa çıkmaya çalışabilirler (Lazarus ve Folkman, 1985). Duygusal odaklı bir başa çıkma stratejisi olan kaderci düşünce önlem alma davranışlarında azalmaya yol açabilir (Lindell ve Perry, 1992), çünkü kaderci kişi stresli bir yaşam olayının zararlarını azaltmak için bir şey yapamayacağına inanabilir. Başka bir ifadeyle, salgının kontrol edilememesi düşüncesi nedeniyle kişi bir salgına yakalanmak konusunda endişelenmenin ve salgına önlem alma davranışları için çaba harcamanın gereksiz olduğunu düşünebilir. $\mathrm{Bu}$ bakımdan kaderci düşünce, insanların salgına önlem almamasına neden olabilecek faktörlerden biri olabilir. Bir başka duygusal odaklı başa çıkma stratejisi olan çaresizlik, önlem alma davranışlarında azalmaya yol açabilir (McClure, Walkey, Allen, 1999). Salgın tehdidinin kontrol edilemez olduğu düşüncesi çaresizlik düşüncesi ile benzerlik göstermektedir ve bu nedenle insanlar salgının kontrol edilemediğini düşündükleri için salgının etkilerinin de kontrol edilemez olduğu sonucuna varmaktadır.

\section{Önlem Alma Davranıșı}

$\mathrm{Bu}$ araştırmada salgınlara önlem alma davranışı Kaynakların Olaya Göreceliği Modeli çerçevesinde incelenmiştir(Mulilis \& Duval, 1997). Lazarus ve arkadaşlarının stres, başa çıkma ve bilişsel değerlendirme konusundaki çalışmalarına dayanan Kaynakların Olaya Göreceliği Modeli (Mulilis \& Duval, 1997), bireylerin olumsuz tehdit edici durumlar ile karşı karşıya 
kalmaları ile problem odaklı başa çıkma tarzını vurgulamaktadır. Problem odaklı başa çıkmada iki bilişsel değerlendirme süreci önemli yer tutmaktadır. Birincisi olayın risk boyutunun değerlendirilmesi, ikincisi ise tehdit yönetiminde kullanılabilecek kişisel baş etme kaynakların değerlenmesidir (Mulilis ve Duval, 1997). Yani problem odaklı başa çıkma tarzı, tehdit edici olayın zarar, risk derecesinin büyüklüğü ve başa çıkma kaynaklarının yeterliliği ile ilişkilidir (Duval ve Mulilis, 1999). Kaynakların Olaya Göreceliği Modeline göre kişi, kendi başa çıkma kaynaklarını olayın algılanan riskinin büyüklüğüne göre nitelik ve nicelik açısından yeterli olarak değerlendirir ve bir denge olduğunu düşünürse problem odaklı başa çıkma tarzını benimseyecektir ( akt. , Şakiroğlu). Aksi takdirde, kişi başa çıkma kaynaklarını yetersiz olarak değerlendirildiğinde, tehdidin algılanan seviyesindeki artış, problem odaklı başa çıkma çabalarını azaltacaktır (Mulilis ve Duval, 1997). Model pandemi sürecine uyarlandığında, virüsün bulaşmasına karşı alınan önlem alma davranışlarının problem odaklı baş etme tarzını harekete geçireceğini, kişinin, kişisel baş etme kaynaklarını yeterli (önlem almanın algılanan zorluğu), olayın yarattığı riski( önlem almanın algılanan faydası) ise uygun ölçüde algılarsa problem odaklı yaklaşımı benimseyeceğini ve önlem alacağını öne sürebiliriz. Bu modele göre kişinin önlem alma becerisini yüksek algılaması ve önlem almanın bulaşma riskini azaltacağına inanması kişisel kaynaklar olarak değerlendirilirken, bulaşma riskinin gerçekleşmesi riski ve vereceği muhtemel zararlara yönelik kişilerin bireysel düşünceleri "olay değişkeni” olarak ele alınmıştır. Bunların arasındaki ilişki problem odaklı baş etme tarzını benimsemeye ve böylelikle virüse karşı önlem alma davranışına yol açacaktır (Mulilis \& Duval, 1997). Bu nedenle çalışmada tek tek önlem alma davranışlarının miktarı ile birlikte o önlemin kişi tarafindan ne kadar faydalı olarak algılandığı ve o önlemi almanın ne kadar zor olduğu bilgileri de toplanacaktır. Faydalı olarak algılanan ve tatbik etmenin görece kolay olduğu önlemlerin daha fazla alınacağı ön görülebilir.

\section{Araştırmanın amacı}

Çalışma kapsamında 18 yaş ve üzeri bireylerde salgına yönelik önlem alma davranışlarının incelenmesi amaçlanmıştır. Bu kapsamda; Salgın sürecinde alınan önlem davranışları ve bunların baş etme yolları ile ilişkisi incelenmiştir. Önlem alma davranışının algılanan zorluğunun, faydalılığının ve algılanan sorumluluğun önlem alma miktarı ile ilişkisi incelenmiştir.

\section{Yöntem \\ Örneklem}

$\mathrm{Bu}$ çalışmaya toplamda 319 kişi katılmıştır. Kontrol maddesine verilen yanıtların incelenmesi sonucunda 20 katılımcının verdiği cevaplar analize dahil edilmemiştir. $\mathrm{Bu}$ çalışmada yaşları 19 ile 76 (Ort: 43.5, SS: 11.4) arasında değişen toplamda 299 kişinin cevapları analiz edilmiştir. Bunların \%69.2'si kadın, \%30.8'i ise erkektir. Araştırmaya en çok katılımcıların \%12.70'ini oluşturan Aydın (38 kişi) ve diğer \%12.70'lik kısmı oluşturan İzmir ( 38 kişi) şehirlerinde ikamet eden kişiler katılmıştır. Diğer şehirlere dair katılımcı sayısı Tablo 1 'de özetlenmiştir. 


\begin{tabular}{llllll}
\hline \multicolumn{5}{c}{ Tablo 1: Şehirlere Göre Katılımcı Sayısının Dağllımı } \\
\hline Şehir & Katılımc & Şehir & Katılımcı & Şehir & Katılımcı \\
& Sayısı & & Sayısı & & Sayısı \\
Aydın & 38 & Sakarya & 5 & Elazı̆ & 1 \\
İzmir & 38 & Diyarbakır & 4 & Yozgat & 1 \\
Bursa & 18 & Ordu & 4 & Düzce & 1 \\
Manisa & 15 & Malatya & 4 & Muş & 1 \\
İstanbul & 14 & Uşak & 4 & Tunceli & 1 \\
Ankara & 13 & Gaziantep & 3 & Şırnak & 1 \\
Denizli & 13 & Niğde & 3 & Bingöl & 1 \\
Antalya & 11 & Çanakkale & 2 & Kars & 1 \\
Eskişehir & 10 & Burdur & 2 & Edirne & 1 \\
Konya & 9 & Zonguldak & 2 & Aksaray & 1 \\
Mersin & 7 & Şanlıurfa & 2 & Yalova & 1 \\
Hatay & 6 & Erzincan & 2 & Iğdır & 1 \\
Tekirdağ & 6 & Erzurum & 2 & Sinop & 1 \\
Kütahya & 6 & Kahramanmaraş & 2 & Çorum & 1 \\
Muğla & 6 & Samsun & 2 & Bitlis & 1 \\
Adana & 5 & Balıkesir & 2 & Karabük & 1 \\
Afyonkarahisar & 5 & Trabzon & 2 & Kırklareli & 1 \\
Kayseri & 5 & Karaman & 2 & Bakü & 1 \\
Kocaeli & 5 & Artvin & 1 & Adıyaman & 1 \\
\hline
\end{tabular}

\section{Veri Toplama Araçları}

Araştırmanın verileri bu çalışmanın amaçları doğrultusunda geliştirilen bir soru çizelgesi ile toplanmıştır. Pandemiye karşı alınan önlem davranışları ile ilgili çok sayıda konuyu araştıran bu soru çizelgesi altı formdan oluşmaktadır: demografik bilgi formu, algılanan sorumluluk ölçümü, önlem alma ve almama nedenleri formu, Salgına Önlem Ölçeği ve Baş Etme Yolları Ölçeği (Ways of Coping).

\section{Demografik Bilgi Formu}

$\mathrm{Bu}$ form standart bir ölçek olmayıp araştırmacılar tarafından hazırlanmıştır. Bu formda katılımcılara yaşlarına, cinsiyetlerine ve evde kimlerle yaşadıklarına dair sorular sorulmuştur.

\section{Algılanan Sorumluluk Ölçümü}

$\mathrm{Bu}$ ölçek standart bir ölçek olmayıp araştırmacılar tarafından hazırlanmıştır. Katılımcılara salgına karşı önlem almanın kimin sorumluluğunda olduğunu düşündükleri sorulmuş ve katılımcılardan; kişinin kendisinin, belediyenin, valiliğin, sağlık bakanlığının veya devletin seçeneklerini sorumluluk derecesine göre sıralamaları istenmiştir.

\section{Önlem Alma ve Almama Nedenleri Formu}

$\mathrm{Bu}$ ölçek standart bir ölçek olmayıp araştırmacılar tarafindan hazırlanmıştır. Katılımcılara salgına yönelik önlem alma ve alma nedenlerinin bulunduğu 12 'şer madde verilerek, katılımcılardan kendilerine uygun olanları işaretlemeleri istenmiştir.

\section{Salgına Önlem Ölçeği}

$\mathrm{Bu}$ ölçek standart bir ölçek olmayıp araştırmacılar tarafindan hazırlanmıştır. Önlem alma davranışları, önlemin algılanan zorluğu ve algılanan faydalılığına yönelik üç kategoriye ait sorulardan oluşan üç ayrı form içermektedir. Önlem alma davranışları: salgın boyunca katılımcıların listelenen önlemleri ne sıklıkla aldığına dair soruları içermektedir. Önlem almanın algılanan zorluğu; salgın boyunca katılımcıların listelenen önlemleri ne kadar zor bulduklarına dair soruları içermektedir. Önlem almanın algılanan faydalılığı; salgın boyunca katılımcıların listelenen önlemleri ne kadar faydalı bulduklarına dair soruları içermektedir. Yapılan analiz 
sonuçlarına göre: Önlem alma davranışları formunun iç tutarlılığına ilişkin Cronbach Alpha değeri .79 bulunmuştur. Önlem almanın algılanan faydalılığ formunun iç tutarlılığına ilişkin Cronbach Alpha değeri .85 bulunmuştur. Önlem almanın algılanan zorluğu formunun iç tutarlılığına ilişkin Cronbach Alpha değeri .84 bulunmuştur.

\section{Baş Etme Yolları Ölçeği (Ways Of Coping)}

Baş etme yolları ölçeği, bireylerin stresli durumlar karşısında hangi yöntemleri kullandıklarını belirlemek amacıyla kullanılan bir öz bildirim ölçeğidir. Bu ölçek Folkman ve Lazarus (1988) tarafindan 66 madde olarak geliştirilmiştir. Başta 66 maddelik olan bu ölçek Karancı, Alkan, Akşit, Balta, ve Sucuoğlu (1999)'nun depremden sağ kurtulan bireyler ile yaptıkları çalışmada ölçek kısaltılarak 42 maddelik bir formda, insanların sıkıntılı olduğu zamanlarda ne tür başa çıkma stratejileri izlediklerini öğrenmek amacıyla kullanılmıştır. Ölçeğin cevap format1 3'lü yanıt kategorisine sahiptir ( 1 = hiçbir zaman, 2 = bazen, $3=$ her zaman). Ölçeğin Cronbach Alpha iç tutarlılık katsayısı .76 olarak hesaplanmıştır. Bu çalışmada ölçeğin faktörlerini belirlemek amacıyla faktör analizi yapılmıştır. Analiz sonucunda elde edilen alt boyutlar şunlardır; problem odaklı- iyimser baş etme yaklaşımı, kaderci yaklaşım, kendini suçlayıcı yaklaşım ve sosyal destek arama. Tüm ölçeğin iç tutarlılık kat sayısı .80 olarak bulunmuştur. Bu çalışmada, ölçeğin faktör analizinin sonuçlarına göre, toplam varyansın \%14.3'ünü açıklanmaktadır. 15 tane madde problem odakl1- iyimser baş etme boyutunda toplanmıştır. Bu alt boyutun iç tutarlılığına ilişkin Cronbach Alpha değeri .85 bulunmuştur. 7 tane madde kaderci yaklaşım boyutunda toplanmıştır. Bu alt boyutun iç tutarlılığına ilişkin Cronbach Alpha değeri .84 bulunmuştur. 4 tane madde kendini suçlayıcı yaklaşım boyutunda toplanmıştır. Bu alt boyutun iç tutarlılı̆̆ına ilişkin Cronbach Alpha değeri .62 bulunmuştur. 4 tane madde sosyal destek arama boyutunda toplanmıştır. Bu alt boyutun iç tutarlılığına ilişkin Cronbach Alpha değeri .50 bulunmuştur.

Tablo 2: Baş Etme Yolları Ölçeğinin Faktör Yükleri

Ölçeğin Alt Boyutları

İçerdiği Maddeler

Cronbach Alpha

Değerleri

Problem Odakl1- İyimser Baş Etme (3, 6, 7, 8, 11, 19, 22, 23, 25, 27, 28, 31, 38, 39, 42 )

Kaderci Yaklaşım

$(10,14,15,20,24,34,37)$

Kendini Suçlayıcı Yaklaşım

$(12,33,35,40)$

.62

Sosyal Destek Arama

$(4,13,18,21)$

.50

\section{İşlem}

Bilgilendirilmiş onam formunu okuyup onay veren katılımcılara, demografik özellikleri konusunda bilgi toplamaya yönelik soruları ve araştırmada kullanılan ölçekleri içeren bir anket formu verilmiştir. Veriler, belirtilen ölçekler aracılığıyla internet üzerinden toplanmıştır. Çalı̧̧maya katılmak ve çalışmayı tamamlamak gönüllülük esasına dayanmıştır

\section{Bulgular}

Alınan önlemlere ilişkin yapılan frekans analizinde ise en çok işaretlenen önlem alma davranışı maddesi katılımcıların \%96,7'sinin seçimi ile "Dışarıdan geldiğimde ellerimi bol su ve sabun ile yıkadım" maddesi olmuştur. Bu maddeyi katılımcıların \%93,3'ünün seçimiyle "Evden dışarı çıkmam gerektiği durumlarda maske taktım" maddesi takip etmiştir. Bu önlemler, virüse karşı yetkililer tarafından önemine fazlaca vurgu yapılmış olan önlemlerdir. En az işaretlenen önlem alma davranışı maddesi ise katılımcıların \%1'inin seçimi ile "Evde eldiven taktım" 
maddesi olurken bu maddeyi katılımcıların \%1,7'sinin seçimi ile "Evde maske taktım" maddesi takip etmiştir.

Tablo 3: Önlem alma davranışlarına ilişkin frekans değerleri

\begin{tabular}{|c|c|}
\hline Maddeler & $\begin{array}{l}\text { Katılımcıların } \\
\text { zaman"' yer } \\
\text { yüzdesi }\end{array}$ \\
\hline Dışarıdan geldiğimde ellerimi bol su ve sabun ile yıkadım & $\% 96$ \\
\hline Evden dışarı çıkmam gerektiği durumlarda maske taktım & $\% 93$ \\
\hline $\begin{array}{l}\text { Evden dışarı çıkmam gerektiği durumlarda fiziksel (sosyal) mesafeye dikkat } \\
\text { ettim }\end{array}$ & $\% 87$ \\
\hline Hapşururken bir peçete ya da kolumun iç kısmı ile ağzımı kapattım & $\% 86$ \\
\hline Kalabalık yerlere gitmekten kaçındım & $\% 83$ \\
\hline Salgına önlem almak amacıyla evdeki odaları düzenli olarak havalandırdım & $\% 81$ \\
\hline Virüs riski nedeniyle iş ya da tatil seyahatlerimi iptal ettim & $\% 79$ \\
\hline Virüs bulaşma riskinden dolayı eve misafir davet etmedim & $\% 79$ \\
\hline Dışarıdan geldiğimde giysilerimi hemen değiş̧irdim & $\% 77$ \\
\hline $\begin{array}{l}\text { Birlikte yaşadığım insanların kullandığı çatal ve kaşıklar yüksek sıcaklıkta } \\
\text { yıkanmadan onları kullanmadım }\end{array}$ & $\% 76$ \\
\hline Dışarıda olduğum süre boyunca dezenfektan/kolonya kullandım & $\% 61$ \\
\hline Evin içinde bulunan yüzeyleri çamaşır suyu, sirke vb. ile temizledim & $\% 60$ \\
\hline $\begin{array}{l}\text { Virüs nedeniyle temel ihtiyaçlarımı karşılamam gereken durumlar dışında evden } \\
\text { çıkmadım }\end{array}$ & $\% 60$ \\
\hline Alışveriş sonrası poşetleri ve aldığım ürünleri dezenfekte ettim & $\% 56$ \\
\hline Salgın nedeniyle bağışıklığımı güçlendirecek tarzda beslenmeme dikkat ettim & $\% 54$ \\
\hline En az 1 hafta yeterli su ve gida depoladım & $\% 51$ \\
\hline Tüm aile üyeleri ayrı havlu kullandı & $\% 46$ \\
\hline Dışarıdan geldiğimde giysilerimi yıkadım & $\% 44$ \\
\hline Her yüzeye dokunuşumda elimi yıkadım ya da dezenfekte ettim & $\% 39$ \\
\hline Evden dışarı çıkmam gerektiği durumlarda eldiven taktım & $\% 30$ \\
\hline
\end{tabular}


Salgını Aldığımız Önlemler mi Yavaşlattı: Salgına Önlem Alma Miktarı ile Önlemlerin...

Evde maske taktım $\% 2$

Evde eldiven taktım $\% 1$

Önlem alma nedenlerine yönelik yapılan frekans analizinde ise en çok işaretlenen madde katılımcıların \%97,9'unun seçimi ile "Ailemi korumak için" maddesi olmuştur ve bu maddeyi katılımcıların \%97,6'sının seçimi ile "Kendimi korumak için" maddesi takip etmiştir. $\mathrm{Bu}$ bulgu katılımcıların bu önlemleri çoğunlukla ailelerini ve kendilerini korumak için aldıklarını göstermektedir. Önlem alma nedeni olarak en az işaretlenen madde ise katılımcıların \%17,4'ünün seçimiyle "Siyasetçiler önlem alma konusunda uyarıda bulunduğu için" maddesi olmuştur ve bu maddeyi katılımcıların \%26,7'si ile "Diğer insanlarda önlem aldığı için" maddesi takip etmiştir. Bu bulgu politikacıların uyarılarının ve öteki insanların eylemlerinin, diğer önlem alma nedenlerine kıyasla daha az önem arz ettiğini göstermektedir. Diğer önlem alma nedenlerine ilişkin değerler Tablo 4' de özetlenmiştir.

Tablo 4: Önlem alma nedenlerine ilişkin frekans değerleri

\begin{tabular}{|c|c|}
\hline Önlem Alma Nedenleri & Yüzdeler \\
\hline Ailemi korumak için & $\% 97.9$ \\
\hline Kendimi korumak için & $\% 97.6$ \\
\hline Toplumu korumak için & $\% 87.3$ \\
\hline Virüsün bulaşmasından korktuğum için & $\% 85.6$ \\
\hline Virüsün neden olduğu hastalık ağır ve acı dolu olduğu için & $\% 84.9$ \\
\hline Bilim insanları önlem alma konusunda uyarıda bulunduğu için & $\% 76.2$ \\
\hline Çevremdekilere örnek olmak için & $\% 44.5$ \\
\hline Virüs açısından riskli bölgede yaşadığım için & $\% 32.1$ \\
\hline Bağışıklık sistemimin zayıf olduğunu düşündüğüm için & $\% 32.1$ \\
\hline Yaşım yüksek olduğu için & $\% 30.1$ \\
\hline Diğer insanlar da önlem aldığı için & $\% 26.7$ \\
\hline Siyasetçiler önlem alma konusunda uyarıda bulunduğu için & $\% 17.4$ \\
\hline
\end{tabular}

Önlem almama nedenlerine yönelik yapılan frekans analizinde ise en çok işaretlenen madde katılımcıların \%35,8'inin seçimi ile "Virüs açısından güvenli bölgede yaşadığım için" maddesi olmuştur ve bu maddeyi katılımcıların \%27,7'sinin seçimiyle "Işe gitmek zorunda olduğum için" maddesi takip etmiştir. Bu bulgu katılımcıların çoğunlukla yaşadıkları yer ve çalışmak zorunda olmaları sebebiyle önlem almadıklarını göstermektedir. Önlem almama nedeni olarak en az işaretlenen madde ise katılımcıların \%1,7'sinin seçimiyle "Ne tür önlemler alabileceğimi bilmediğim için" maddesi olmuştur ve bu maddeyi katılımcıların \%4,01'inin seçimiyle "Diğer insanlar da önlem almadığı için" maddesi takip etmiştir. Bu bulgu, bilgi 
eksikliğinin ve öteki insanların eylemlerinin, diğer önlem almama nedenlerine kıyasla daha az önem arz ettiğini göstermektedir. Diğer önlem almama nedenlerine ilişkin değerler Tablo 5' te özetlenmiştir.

Tablo 5: Önlem Almama Nedenlerine İlișkin Frekans Değerleri

\begin{tabular}{ll}
\hline Önlem Almama Nedenleri & Yüzdeler
\end{tabular}

Virüs açısından güvenli bölgede yaşadığım için

$\% 35.8$

İşe gitmek zorunda olduğum için

İhmalkarlık

Alınması gereken önlemler özgürlüğümü kısıtladığg için

Ne de olsa bir gün hepimizin virüse yakalanacağını düşündüğüm için

Salgının etkilerinin abartıldığını düşündüğüm için

Sağlığıma güvendiğim için

Virüse yakalanmak kaderimde varsa, önlem alarak bunu değiştiremeyeceğimi düşündüğüm \%10.03 için

Maddi yetersizlikten dolayı (maske, eldiven, dezenfektan vb. almak için yeterli maddi güce sahip olmadığım için)

Bana bir şey olmayacağını düşündüğüm için

Diğer insanlar da önlem almadığı için

Önlem alma davranışının cinsiyet değişkeni açısından farklılaşıp farklılaşmadığını belirlemeye yönelik yapılan bağımsız örneklem $t$ testi sonucuna göre salgına önlem alma ölçeğinden elde edilen puanlar cinsiyetler arasında anlamlı bir farklılık göstermektedir. Kadınların salgına önlem alma ölçeğinden aldıkları puanların ortalaması $(\mathrm{M}=1.51, \mathrm{SE}=.01)$ erkeklerin aynı ölçekten aldığ puanların ortalamasından $(\mathrm{M}=1.33, \mathrm{SE}=.03)$ anlamlı ölçüde fazladır ve bu fark orta büyüklükte bir etkiyi temsil etmektedir (t[297] $=-6.09, \mathrm{p}=.00, \mathrm{~d}=.71$ ).

Tablo 6: Önlem Alma Davranışının Cinsiyetler Arası Farkının Bağımsız Örneklem T Testi

\begin{tabular}{lccccccc}
\hline Değişken & \multicolumn{2}{c}{ Levene Testi } & T & df & P & $\begin{array}{l}\text { \%95 } \\
\text { Aralı̆̆ }\end{array}$ & Güven \\
\hline $\begin{array}{l}\text { Önlem } \\
\text { Davranışı }\end{array}$ & 15.29 & 0.000 & & & & & {$[-0.235-0.120]$} \\
\end{tabular}

Bağımlı ve bağımsız değişkenler arasındaki ilişkileri incelemek amacıyla yapılan korelasyon analizi sonuçları tablo 7'de özetlenmiştir. 
Tablo 7: Bağımlı ve Bağımsız Değișkenlerin Pearson Korelasyon Değerleri

\begin{tabular}{|c|c|c|c|c|c|c|c|c|}
\hline $\begin{array}{l}\text { Değişkenle } \\
\mathbf{r}\end{array}$ & 1 & 2 & 3 & 4 & 5 & 6 & 7 & 8 \\
\hline $\begin{array}{l}\text { Problem } \\
\text { Odakl1- } \\
\text { İyimser } \\
\text { Başa Etme } \\
\text { Yaklaşımı }\end{array}$ &.. & & & & & & & \\
\hline $\begin{array}{l}\text { Kaderci } \\
\text { Baş Etme } \\
\text { Yaklaşımı }\end{array}$ & 0.087 & .. & & & & & & \\
\hline $\begin{array}{l}\text { Kendini } \\
\text { Suçlayıcı } \\
\text { Baş Etme } \\
\text { Yaklaşımı }\end{array}$ & $-0.250 * *$ & 0.095 & .. & & & & & \\
\hline $\begin{array}{l}\text { Sosyal } \\
\text { Destek } \\
\text { Arama Baş } \\
\text { Etme } \\
\text { Yaklaşımı }\end{array}$ & $0.119^{*}$ & $0.144^{*}$ & $0.205^{* *}$ & .. & & & & \\
\hline $\begin{array}{l}\text { Önlem } \\
\text { Alma } \\
\text { Davranışı }\end{array}$ & $0.177^{* *}$ & 0.068 & 0.021 & 0.017 & .. & & & \\
\hline $\begin{array}{l}\text { Önlemin } \\
\text { Algilanan } \\
\text { Zorluğu }\end{array}$ & $-0.186^{* *}$ & 0.026 & 0.042 & 0.074 & $-0.135^{*}$ & .. & & \\
\hline $\begin{array}{l}\text { Önlemin } \\
\text { Algılanan } \\
\text { Faydalıllığ }\end{array}$ & $0.142 *$ & $0.147^{*}$ & -0.039 & $0.115^{*}$ & $0.411^{* *}$ & $-0.173 * *$ & .. & \\
\hline $\begin{array}{l}\text { Algilanan } \\
\text { Sorumluluk }\end{array}$ & 0.009 & -0.019 & 0.018 & -0.110 & 0.054 & -0.011 & 0.040 &.. \\
\hline
\end{tabular}

Not: $* * \mathrm{p}<0.01, * \mathrm{p}<0.05$

Araştırma hipotezlerinin test edilmesi için yapılan regresyon analizi sonucunda önlemin algılanan faydalılığının, önlem alma davranışını yordadığ bulunmuştur $(B=.42, t=7.77, p$ $<.001, \% 95 \mathrm{CI}[.31 / .52])[\mathrm{F}(1,297)=60.3, \mathrm{p}<.001]$. Bu iki değişken arasında pozitif yönde ve orta büyüklükte anlamlı bir ilişki vardır $(\mathrm{r}=.41)$ ve önlemin algılanan faydası tek başına önlem alma davranışının varyansının \%17'sini açıklamaktadır $\left(\mathrm{R}^{2}=.17\right)$. Alınacak önlem ne kadar faydalı algılanırsa önlem o kadar çok uygulanmaktadır. Bununla birlikte önlemin algılanan zorluğu da önlem alma davranışını yordamaktadır( $\mathrm{B}=-.1, \mathrm{t}=-2.34, \mathrm{p}=.02, \% 95 \mathrm{CI}[-.18 /-.02])$ $[\mathrm{F}(1,297)=5.5, \mathrm{p}=.02]$ fakat bu iki değişken arasında beklenildiği gibi negatif yönde anlamlı 
bir ilişki bulunmaktadır $(\mathrm{r}=.13)$. Önlemin algılanan zorluğu da tek başına önlem alma davranışının varyansının \%2'sini açıklayabilmektedir $\left(\mathrm{R}^{2}=.02\right)$. Önlemin algılanan zorluğu arttıkça önlemin alınma miktarı azalmaktadır. Bununla birlikte yapılan regresyon analizi sonucunda algilanan sorumluluk $(\mathrm{B}=.01, \mathrm{t}=.94, \mathrm{p}=.35, \% 95 \mathrm{CI}[-.01 / .03])[\mathrm{F}(1,297)=.88, \mathrm{p}=$ .35] değişkeninin önlem alma davranışını yordama gücüne sahip olmadığı görülmüştür.

Önlem alma davranışı ile baş etme yolları arasındaki ilişkiye ilişkin hipotezlerin test edilmesi amacıyla yapılan regresyon analizleri sonucunda problem odaklı iyimser baş etme yaklaşımının önlem alma davranışını yordayabilme gücüne sahip olduğu bulunmuştur $(B=.14$, $\mathrm{t}=3.10, \mathrm{p}=.002, \% 95 \mathrm{CI}[.05-.22])[\mathrm{F}(1,297)=9.64, \mathrm{p}=.002]$ ve bu iki değişken arasında da pozitif yönde anlamlı bir ilişki bulunmaktadır $(\mathrm{r}=18)$. Problem odaklı-iyimser baş etme yaklaşımı da tek başına önlem alma davranışının varyansının \%3'ünü açıklayabilmektedir $\left(\mathrm{R}^{2}\right.$ $=.03)$. Analiz sonuçlarına göre kaderci baş etme yaklaşımı $(\mathrm{B}=.03, \mathrm{t}=1.18, \mathrm{p}=.24, \% 95 \mathrm{CI}[-$ $.02 / .09])[\mathrm{F}(1,297)=1.39, \mathrm{p}=.24]$, kendini suçlama yaklaşımı $(\mathrm{B}=.01, \mathrm{t}=.36, \mathrm{p}=.72, \% 95$ $\mathrm{CI}[-.05 / .08])[\mathrm{F}(1,297)=.13, \mathrm{p}=.72]$ ve sosyal destek arama $(\mathrm{B}=.01, \mathrm{t}=.29, \mathrm{p}=.77, \% 95 \mathrm{CI}[-$ $.06 / .08])[\mathrm{F}(1,297)=.09, \mathrm{p}=.77]$ değiş̧kenlerinin her birinin önlem alma davranışını yordama gücüne sahip olmadığı görülmüştür.

Her biri önlem alma davranışının anlamlı bir yordayıcısı olan problem odaklı-iyimser baş etme yaklaşımı, önlemin algılanan zorluğu ve önlemin algılanan faydası değişkenleri ise hep birlikte önlem alma davranışındaki varyansın \%18'ini açıklayabilmektedir $\left(\mathrm{R}^{2}=.18,[\mathrm{~F}(2\right.$, 296) $=22.39, \mathrm{p}=.00)$ ]. Bu bağımsız değişkenlere ilişkin regresyon analizi sonuçları Tablo 8'de özetlenmiştir.

Tablo 8: Önlem Alma Davranışının Bağımlı Değişken Olarak Alındığı Doğrusal Regresyon Analizi

\begin{tabular}{lllll}
\hline Değişken & $\begin{array}{l}\text { Regresyon } \\
\text { Katsayısı }\end{array}$ & Standart Hata & $\mathbf{P}$ & $\begin{array}{l}\mathbf{\% 9 5} \\
\text { Aralı̆̆ı }\end{array}$ \\
\hline $\begin{array}{l}\text { Önlemin Algılanan } \\
\text { Faydalılığı }\end{array}$ & 0.419 & .054 & 0.000 & {$[0.313-0.526]$} \\
$\begin{array}{l}\text { Önlemin Algılanan } \\
\text { Zorluğu }\end{array}$ & -0.099 & 0.042 & 0.020 & {$[-0.182--0.016]$} \\
$\begin{array}{l}\text { Algılanan } \\
\text { Sorumluluk }\end{array}$ & 0.009 & 0.010 & 0.350 & {$[-0.010-0.029]$} \\
$\begin{array}{l}\text { Problem Odaklı- } \\
\text { Iyimser Başa Etme } \\
\text { Yaklaşımı }\end{array}$ & 0.137 & 0.044 & 0.002 & {$[0.050-0.224]$} \\
$\begin{array}{l}\text { Kendini Suçlayıcı } \\
\text { Başs }\end{array}$ & 0.012 & & & \\
$\begin{array}{l}\text { Yaklaşımı Etme } \\
\text { Kaderci Baş Etme }\end{array}$ & 0.035 & 0.034 & 0.717 & {$[-0.055-0.080]$} \\
Yaklaşımı & & 0.030 & & {$[-0.023-0.093]$} \\
$\begin{array}{l}\text { Sosyal Destek } \\
\text { Arama Baş Etme } \\
\text { Yaklaşımı }\end{array}$ & 0.011 & 0.036 & 0.240 & {$[-0.060-0.081]$} \\
\hline
\end{tabular}

Process kullanılarak yapılan aracılık analizi sonucunda önlemin algılanan zorluğu ile önlem alma arasındaki ilişkiye önlemin algılanan faydalılığı değişkenin aracılık ettiği bulunmuştur ( $\mathrm{B}=-.051, \% 95 \mathrm{CI}[-.10,-.01])$. 
Şekil 1: Algılanan Zorluk ve Önlem Alma Arasındaki İlişkide Algılanan Faydalılığın Arac1lık Etkisi

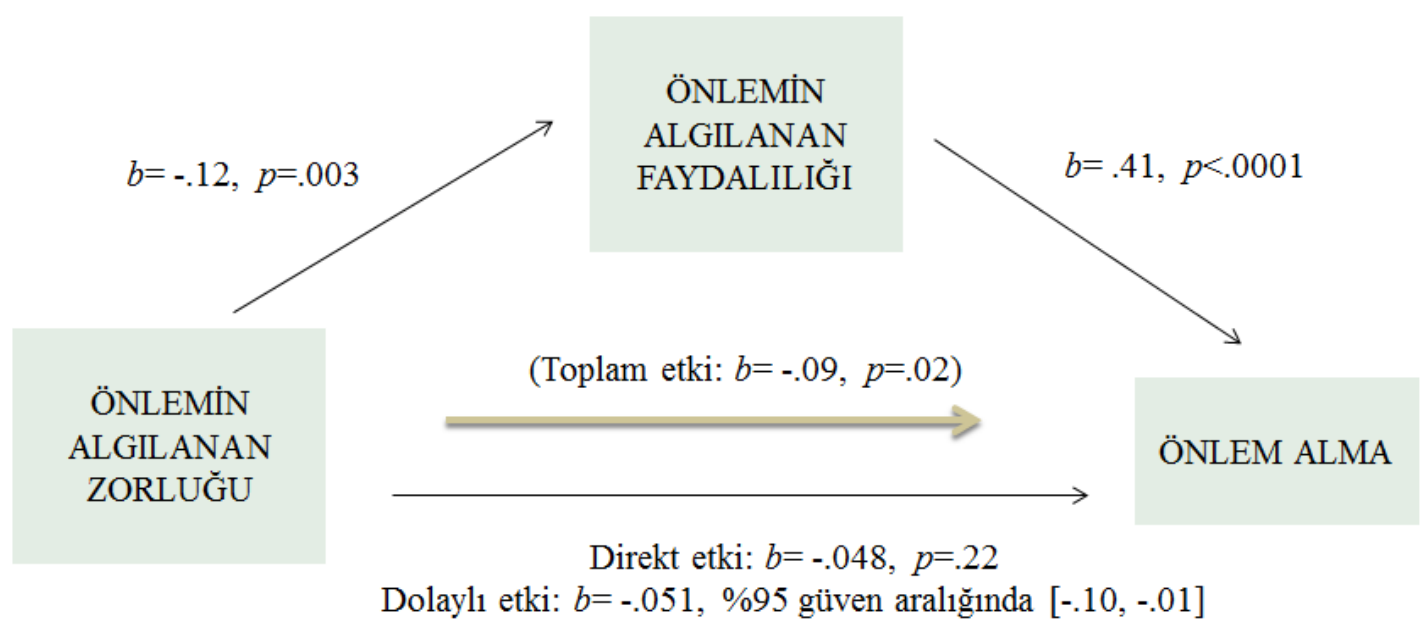

Bir diğer aracılık analizi sonucunda ise problem odakl1- iyimser baş etme ile önlem alma arasındaki ilişkiye önlem almanın algılanan faydalılığı değişkeninin tam aracılık ettiği bulunmuştur $(\mathrm{B}=.04, \% 95 \mathrm{CI}[.01, .08])$.

Şekil 2: Problem Odaklı- İyimser Baş Etme ve Önlem Alma Arasındaki İlişkide Algılanan Faydalılığın Aracılık Etkisi

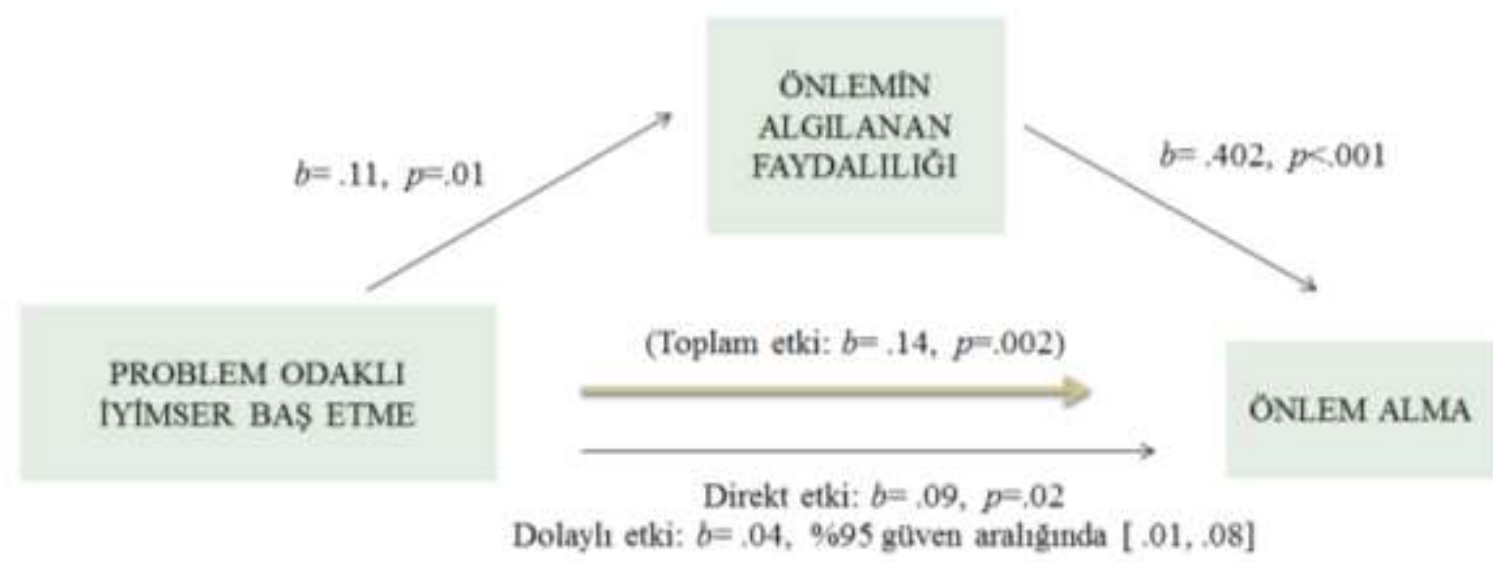

\section{Tartışma}

Salgın sürecinde önlem alma davranışını etkileyen psikolojik faktörleri belirlemek amacıyla yapılan bu çalışmada elde edilen bulgular araştırma hipotezlerinin bir kısmını desteklerken bir kısmını desteklememiştir. Problem odaklı-iyimser baş etme yaklaşımının, önlemin algılanan faydalılığının ve önlemin algılanan zorluğunun önlem alma davranışını yordayacağına ilişkin hipotezler araştırma bulgularınca desteklenmiştir. Bunun yanı sıra kaderci başa çıkma yaklaşımının, sosyal destek aramanın, algılanan sorumluluğun ve kendini suçlama yaklaşımının önlem alma davranışını yordayacağına ilişkin hipotezler araştırma bulgularınca istatistiksel olarak anlamlı sonuçlarla desteklenememiştir. Bu beklenmedik sonuca baş etme 
yolları ölçeğine ilişkin yapılan faktör analizi sonucunda sosyal destek arama ve kendini suçlayıcı yaklaşım alt boyutlarının ağırlıklı olarak teorik uygunluk baz alınarak oluşturulması neden olmuş olabilir. Bununla birlikte araştırma bulgularına göre, salgın sürecinde pek çok alanda alınan önlem miktarının genel olarak yüksek olduğu görülmüştür. Bu bulgular ülkemizde salgın sürecinin diğer ülkelere kıyasla daha az kayıpla atlatılmış olmasının sebebi olarak yorumlanabilir. Önlemin algılanan faydasının önlem alma davranışını yordadığı bulgusu göz önüne alındığında kişileri önlemin faydası konusunda kitle iletişim araçları yoluyla daha fazla bilgilendirmek önlem alma davranışının artmasında oldukça önemli bir yeri olduğu düşünülmektedir. Önlemin algılanan faydasının önlemin algılanan zorluğu ve önlem alma davranışı arasındaki ilişkiye aracılık ettiği bulgusu göz önüne alındığında kitle iletişim araçları yoluyla insanların önlemin faydalılı̆̆ konusunda ikna edilmeleriyle, önlem alma davranışı zor olarak algılansa dahi önlemi uygulayacakları düşünülmektedir. Problem odakl1-iyimser baş etme yaklaşımını benimseyen kişilerin daha fazla önlem alması sebebiyle kişilerin bu yaklaşımını benimsemesini engelleyebilecek salgına yönelik komplo teorilerine ilişkin kişilerin bilgilendirilmesi önlem alma davranışında artışa neden olacağ düşünülmektedir. Salgın gibi küresel kriz dönemlerinde komplo teorilerinin daha da artması ve bu teorilerin insanların önlem alma davranışları üzerinde etkisinin olması bu konuyu üzerinde durmaya değer bir konu haline getirmektedir (Bavel vd., 2020).

\section{Kaynakça}

Aktürk, H. (2020). Yeni koronavirüs hastalığı pandemisi döneminde online yaşam ve psikolojik etkileri. Ankara Üniversitesi Sağllk Bilimleri Enstitüsü. Erişim Tarihi:22.05.2020. https://www.academia.edu/43045398/Yeni_Koronavir\%C3\%BCs_Hastal\%C4\%B1

Bavel, V. J. J., Baicker, K., Boggio, P. S., Capraro, V., Cichocka, A., Cikara, M., \& Drury, J. (2020). Using social and behavioural science to support COVID-19 pandemic response. Nature Human Behaviour, 460-472.

Bayraktaroğlu, S., Y1lmaz, S. E. ve Murat, C. A. N. (2014). Kurumsal sosyal sorumluluk algısının örgütsel bağlılığa etkisini belirlemeye yönelik bir araştırma. Siyaset, Ekonomi ve Yönetim Araştırmaları Dergisi, 2(3), 99-122.

Bedford, J., Enria, D., Giesecke, J., Heymann, D. L., Ihekweazu, C., Kobinger, G., \& Ungchusak, K. (2020). COVID-19: towards controlling of a pandemic. The Lancet, 395(10229), 1015-1018. doi: 10.1016/S0140-6736(20)30673-5.

Carver, C. S., Weintraub, J. K., \& Scheier, M. F. (1989). Assessing coping strategies. A heoretically based approach. Journal of Personality and Social Psychology, 56(2), 267283. https://doi.org/10.1037/0022-3514.56.2.267

Duval, S. T., \& Mulilis, J. P.(1999). A person relative to event (PrE) Approach to negative threat appeals and earthquake preparedness: A field study. Journal of Applied Social Psychology, 29,(3), 495-516. https://doi.org/10.1111/j.1559 1816.1999.tb01398.x

Folkman S, \& Lazarus R. S. (1980). An analysis of coping in a middle-aged community sample. Journal of Health and Social Behavior, 21, 219-39. https://doi.org/10.2307/2136617

Folkman, S., \& Lazarus, R. S. (1988). The relationship between coping and emotion: Implications for theory and research. Social Science \& Medicine, 26(3), 309-317. https://doi:10.1016/0277-9536(88)90395-4

Folkman, S., \& Lazarus, R. S. (1985). If it changes it must be a process: Study of emotion and coping during the three stages of a college examination. Journal of Personality and Social Psychology, 48(1), 150-170. https://doi.org/10.1037/0022-3514.48.1.150 
Folkman, S., \& Moskowitz, J. T. (2000). Stress, positive emotion and coping. Current Directions in Psychological Science, 9(4), 115-118. https://doi.org/10.1111/14678721.00073

İşsever, H., İşsever, T., \& Öztan, G. (2020). COVID-19 epidemiyolojisi. Sağlık Bilimlerinde İleri Araştırmalar Dergisi, 3(1), 9-21. doi: 10.26650/JARHS2020-S1-0001

Karancı, N. A., Alkan, N., Akşit, B., Sucuoğlu, H., \& Balta, E. (1999). Gender differences in psychological distress, coping, social support and related variables following the 1995 Dinar (Turkey) earthquake. North American Journal of Psychology, 1 (2),

189204.

Lazarus, R. S., \& Folkman, S. (1984). Stress, appraisal, and coping. Springer publishing company. https://doi.org/10.1007/978-1-4419-1005-9_215

Lindell, M. K. \& Perry, R. W. (1992). Behaviral Foundations of Community Emrgency Planning. Hemisphere Press.

McClure, J., Walkey, F., \& Allen, M. (1999). When earthquake damage is seen as preventable: Attributions, locus of control and attitudes to risk. Applied Psychology:An International Review, 48, 239-256. https://doi.org/10.1111/j.14640597.1999.tb00060.x

Metintaş, S. (2020). COVID-19'un epidemiyolojisi. Avrasya Göğüs Hastalıkları Dergisi, 4-15.

Mulilis, J. P., \& Duval, T. S. (1997). The PrE model of coping and tornado preparedness: Moderating effects of responsibility. Journal of Applied Social Psychology, 27(19), 1750-1766. https://doi.org/10.1111/j.1559-1816.1997.tb01623.x

Sezer, A., \& Çoban, O. (2016). Ortaokul öğrencilerinin sorumluluk değeri algıları. Uşak Üniversitesi Eğitim Araştırmalarl Dergisi, 2(1), 22-39. https://doi.org/10.29065/usakead.232420

Şakiroğlu, M. (2011). Positive outcomes among the 1999 Düzce earthquake survivor. Doctoral dissertation, Middle East Technical University

Türk Dil Kurumu. 'Türk Dil Kurumu- Dilimiz Kimliğimizdir’. Erişim: 17 Mayıs 2020. http://tdk.gov.tr

Unger, J. B., Kipke, M. D., Simon, T. R., Johnson, C. J., Montgomery, S. B., \& Iverson, E. (1998). Stress, coping, and social support among homeless youth. Journal of adolescent research, 13(2), 134-157. https://doi.org/10.1177/0743554898132003 